\title{
Determination of Microbial Properties of Freeze Dried Traditional Cheese
}

\author{
Tuba Büyüksırıt Bedir 1,a,", Hakan Kuleaşan",b \\ ${ }^{\text {I} F o o d ~ E n g i n e e r i n g ~ D e p a r t m e n t, ~ E n g i n e e r i n g ~ F a c u l t y, ~ S u ̈ l e y m a n ~ D e m i r e l ~ U n i v e r s i t y, ~} 32260$ Isparta, Turkey \\ *Corresponding author
}

A R T I C L E I N F O
Research Article

Received : 17/07/2018
Accepted : 18/02/2019

A B S T R A C T

The use of dried cheese in food production and food preparation sectors is becoming increasingly widespread. Dried cheese is preferred because of their longer shelf life at room temperatures, smaller packaging sizes, practical use, and their ease of homogenization in food products. Various technologies are currently being used for the drying of cheese and efforts are still being made to develop new methods. Freeze drying is a highly preferred technique for the production of dried cheese due to high quality of the final product. Instant removal of water and low process temperatures ensure an effective prevention of chemical and microbial deterioration. In this study, White, Kashar and Tulum cheeses were dried by freeze-drying method. Physicochemical analyses were carried out on the first day in order

\section{Keywords:}

White cheese

Kashar cheese

Tulum cheese

Lyophilisation

Freeze drying

to determine the initial quality of cheese samples. The moisture and salt content were highest in White cheese, titratable acidity and fat content were highest in Tulum Cheese. Freze dried cheese samples were stored in room conditions for 6 months and changes in microbial populations such as mesophilic aerobic bacteria, yeast and moulds, lactic acid bacteria, Staphylococci spp. and coliform group bacteria were determined. The results showed that Tulum Cheese contained highest microbial counts in general. The number of bacteria was $7.71 \pm 0.10 \mathrm{log} \mathrm{cfu} / \mathrm{g}$ in Tulum Cheese, $5.70 \pm 0.07 \mathrm{log} \mathrm{cfu} / \mathrm{g}$ in White cheese. Total counts of yeasts and molds were $7.37 \pm 0.06 \mathrm{log}$ cfu/g for Tulum cheese and $4.92 \pm 0.07$ $\log \mathrm{cfu} / \mathrm{g}$ for Kashar Cheese. Statistical analysis was performedby using Minitab Statistical Package Program to evaluate the results of microbiological analysis on dried cheese samples.

\section{Introduction}

Simultaneous use of various factors to prevent microbial growth in order to extend the shelf life of foods is defined as "hurdle technology". Those factors include $\mathrm{pH}$, water activity, temperature, redox potential, present microorganisms, and preservatives (Leistner, 2000). The hurdle effect is a good example proving that in most foods several factors contribute to its stability and safety. This effect is of ultimate importance for the preservation of food, since the hurdles in a food product prevent microbial spoilage and food poisoning as well as some fermentations (Leistner, 1992).

Drying is a food preservation technique which was used since antiquity, and a common process in many chemical and food industries. Drying by various methods prevents the growth and reproduction of microorganisms causing decay and minimizes many of undesired reactions caused by moisture (Dincer et al., 2002). The process involves the slow removal of the majority of water from foods so that the moisture contents of the dried product is lower than
20\% (Andritsos et al., 2003). The method of drying and physicochemical changes occured during the process seem to determine the quality of the final product. Particularly, the method and the process conditions substantially affect the colour, texture, density, porosity and sorption characteristics of materials. Several drying methods have been studied to produce high quality and practical products at a competitive cost (Krokida and Maroulis, 2007). Drying is a widely used method to obtain foods which have longer shelf-lifes and make their marketing easier. Drying ensures the production of stabilized food products from unstable raw materials by lowering water activity to suited levels, thus preventing microbial spoilage and quality losses due to caused by some biochemical reactions (Marques et al., 2009).

Freeze-drying is a drying method that leads to high quality dehydrated products (shape preservation, limited loss and/or alteration of aroma, and quick rehydration etc.) (Genin and Rene, 1996; Hammami and Rene, 1997). 
Freeze-drying is a method of removing water by sublimation from a frozen material. Due to the absence of water in liquid form and the low temperatures applied during the process, most of degradation and microbiological spoilage are prevented, thus providing excellent quality products that compared to products that were dried by conventional methods (Ratti, 2001; Ciurzyńska and Lenart, 2011). Besides low temperatures and the absence of air prevent the degradation of thermolabile, biological and pharmaceutical materials (Savo, 2012; Veras, 2012). The porosity of freeze-dried foods is mainly depend on the speed of freezing. The glass transition temperature is also a significant parameter for the optimization of freeze-drying process (Serna-Cock et al., 2015).

For many years, dried and powdered cheese has been produced and marketed in many countries. The foremost example of such products is Parmesan cheese. In some countries such as Italy, Argentina and America where pasta and pizza consumption are intense, dried cheese is produced and used widely (Kaya, 2004). Dried cheese is mostly used as food industry additives. When compared to traditional conventional classic cheese, there are advantages such as easier mixing, longer shelf life, different flavour and functional properties (Henning et al., 2006). Dried cheeses are used in salad dressing, souffle, cake and some special bakery products such as chips, pasta, biscuits, pizza and soup in the industry. (Kaya, 2004). At the same time it is directly used as a flavouring on hot dishes like spaghetti and soups (Pisecky, 2005). Foodstuffs produced by the addition of cheese powder; can have the same structure, flavour and aroma as cheese-containing foods (Küçüköner, 2011).

The aim of this study is to extend the shelf-life of various cheese types which have high market values by freeze drying and to facilitate their use in the industry. Three types of traditional cheese namely White, Kashar and Tulum cheese were freeze dried. Some quality parameters like dry matter, $\mathrm{pH}$, titration acidity, salt and fat amounts were determined prior to lyophilization process. Microbiological analyses were repeated at 0, 1, 2, 3 and 6 months in dried cheese samples stored in room conditions.

\section{Materials and Methods}

White, Kashar and Tulum cheese samples purchased from local markets were used as a material. Kashar and White cheese were grated while Tulum cheese was crushed and frozen at $-18^{\circ} \mathrm{C}$ for 24 hours in a freezer. Freeze-drying process was performed in lyophilizer equipment (VirTis $\mathrm{K} 2$ Benchtop, USA) at $-60^{\circ} \mathrm{C}$ under $100 \mathrm{mTorr}$ vacuum for 18 hours. After lyophilization process cheese samples were packed and stored at room temperature.

Physical and chemical analysis were performed initially to cheese samples of White, Kashar and Tulum. Dry matter and titratable acidity of the raw materieals were determined according to the methods of AOAC (1990; 2000a). Gerber's method was used to determine the fat content (Anonymous, 1978) and Mohr titration method (AOAC, 2000b) was used for determination of salt content in cheese. $\mathrm{pH}$ of cheese samples were measured using a digital pH-meter (WTW, Germany) at $20^{\circ} \mathrm{C}$. All chemical analyses were performed in duplicate.

\section{Microbiological Analyses}

Ten $g$ of cheese sample weighed in aseptic conditions and placed in $90 \mathrm{~mL}$ of dilution fluid. Serial dilutions up to $10^{-7}$ were done and spread plating method was used for the enumeration of microorganisms. Total microbial counts were determined on Plate Count Agar (PCA, Merck) plates incubated at $30^{\circ} \mathrm{C}$ for 48 hours; Lactic Acid Bacteria (LAB) on DeMan Rogosa Sharpe Agar (MRS, pH 6.2) plates incubated at $30^{\circ} \mathrm{C}$ for 48 hours; yeast and moulds counts was determined on Patato Dextrose Agar (PDA, Merck) plates incubated at $25^{\circ} \mathrm{C}$ for 5 days. Coagulase negative Staphylococci and Coliform Group Bacteria was enumerated on Baird Parker Agar (BPA, Merck) and Eosin Metilen Blue Agar (EMBA, Merck) plates respectively. Both media were incubated at $37^{\circ} \mathrm{C}$ for 48 hours. The results were expressed as log of colony forming units (cfu) per gram of cheese. Microbial enumeration experiments were conducted in triplicates.

\section{Statistical Analyses}

Evaluation of the results obtained from microbial analyses were done by using Minitab Statistical Package Program (Minitab, 1991). The data were presented as mean and standard deviation. One-way analysis of variance was applied in order to determine the presence of significant differences between three samples followed by Duncan's multiple range tests. The significance levels of $\mathrm{P}<0.05$ were used for statistical differences (Düzgüneş et al., 1987).

\section{Results and Discussion}

Determination of Analytical Properties of Cheese Samples prior to lyophilization.

The composition of the cheese samples before drying is shown in Table 1. It can be seen that in general terms that moisture and salt content was highest in White cheese and fat content was highest in Tulum Cheese.

Removal of water from foods is necessary to reduce water activity for the prevention of microorganism growth (Pal et al., 2016). The dry matter of the Kashar cheese samples were found $43.99 \pm 0.38 \%$ and $53.93 \pm 0.55 \%$ in studies done by Karaman and Akbulut (2006) and Temiz (2009) respectively. In another study, Tayar (1995) reported that dry matter of White Cheese ranged between $33.13-36.14 \%$. In various studies dry matter of Tulum Cheese have varied between 58.06-61.09\% (Öner et al., 2005) and 53.21\% (Kurt et al., 1991) in Tulum cheese samples. The values in the current study show similarity to most other work. All cheeses were characterized by having a $\mathrm{pH}$ value ranging from 4.85 to 5.32 .

The fat content of White Cheese was $12.17 \%$ while the fat content of Kashar and Tulum cheese samples were $20.17 \%$ and $32.17 \%$. The differences in fat ratio is mainly depended on the the type of milk (ewe, cow or goat), removal of fat from the milk, cutting blades, and application of different temperatures and times during kneading and scalding (Demirci and Diraman, 1990). Similarly, in various studies the fat content were reported as 16.04-17.75\% (Tayar, 1995) in White cheese, $23.20 \%$ (Temiz, 2009) in Kashar Cheese and 16.0-37.0\% (Kurt et. al., 1991) in Tulum Cheese. The salt content was found highest in White cheese samples. Erbay et al. (2015) reported the salt content of White cheese as $4.3 \%$, while it 
was determined between $4.21-4.83 \%$ in a study conducted by Tayar (1995). In a study the salt content was reported $3.44 \%$ (Kurt et al., 1991) in Tulum cheese. In other studies the salt content of Kashar Cheese was determined as 1.54 $\%$ (Demirci and Diraman, 1990) and 2.82\% (Temiz, 2009).

\section{Microbiological Analysis of Dried Cheese Samples}

Changes in microbial populations throughout six months storage (Total mesophilic aerobic bacteria, yeast and moulds, lactic acid bacteria, Coagulase Negative Staphylococci and coliform group bacteria) of freeze dried cheeses are presented in Table 2. The microflora of cheese may arise from three major sources: microorganisms present in the milk, starter cultures used in the production, and from contaminations during processes (Kongo and Malcata, 2016). In Figure 1 it can be seen that initial number of TMAB in Kashar, Tulum and White cheese samples were 5.90, 7.71 and $5.70 \mathrm{log} \mathrm{cfu} / \mathrm{g}$, respectively. White cheese showed a slight microbial growth after one month, while the other two cheeses showed the same increase after 2 months. TMAB counts gradually decreased in freeze dried cheese samples during 6 months of storage. TMAB results were $2.30 \mathrm{log} \mathrm{cfu} / \mathrm{g}, 5.44 \mathrm{log} \mathrm{cfu} / \mathrm{g}$ and 5.50 $\log \mathrm{cfu} / \mathrm{g}$ in freeze dried Kashar, Tulum and White cheeses respectively. Ozdemir and Demirci (2006) reported TMAB counts in fresh Kashar cheese as $7.15 \mathrm{log} \mathrm{cfu} / \mathrm{g}$ while Çetinkaya and Soyutemiz (2006) have determined as 5.6 $\log \mathrm{cfu} / \mathrm{g}$. In a study conducted by Morul and İşleyici (2012), TMAB in fresh Tulum cheese was $6.78 \mathrm{log} \mathrm{cfu} / \mathrm{g}$ and in another study TMAB counts in fresh White cheese was determined as $6.28 \mathrm{log} \mathrm{cfu} / \mathrm{g}$ (Abdalla et al., 2012).
Yeasts and mold contaminations are frequently caused by reinfection of the final product after manufacturing process. The cheese may can be contaminated by these microorganisms present in the various parts of the production plant like walls and shelves of ripening rooms, air, equipment, water and brine (Papademas, 2006; Kongo and Malcata, 2016). Initial values for yeast and molds in Kashar, Tulum and White cheese samples were $4.92 \mathrm{log}$ cfu/g, $7.37 \log \mathrm{cfu} / \mathrm{g}$ and $5.12 \mathrm{log} \mathrm{cfu} / \mathrm{g}$ (Figure 2). This was thought to be the original microbial load of cheese samples prior to lyophilization. Yeast and mold counts in Kashar, Tulum and White cheese samples were $4.94 \mathrm{log} \mathrm{cfu} / \mathrm{g}$ (Ozdemir and Demirci, 2006); $6.36 \mathrm{log}$ cfu/g (Morul and İşleyici, 2012) and $5.64 \mathrm{log} \mathrm{cfu} / \mathrm{g}$ (Pešić-Mikulec and Jovanović, 2005) respectively.

Lactic Acid Bacteria were the most dominant group of microorganisms in most dairy products. Some most found species in cheese are homofermentative lactic acid bacteria like lactococci or heterofermentatives like lactobacilli. In Figure 3 the changes in LAB counts during 6 months of storage were given. The initial LAB counts in Kashar, Tulum and White cheese were found to be 4.94, 6.97 and $4.92 \mathrm{log} \mathrm{cfu} / \mathrm{g}$ respectively. After storage, a rapid decrease was determined in all cheese samples. Öner et al. (2003) were investigated microbiological properties of 20 Tulum cheese samples and LAB counts were determined as 7.22 $\log \mathrm{cfu} / \mathrm{g}$. LAB counts in Kashar and White cheese samples were $5.49 \mathrm{log} \mathrm{cfu} / \mathrm{g}$ (Badem and Uçar, 2016) and $3.72 \mathrm{log}$ cfu/g (Abdalla et al., 2012).

Table 1 The chemical analysis results of fresh Kashar, Tulum and White cheese samples

\begin{tabular}{l|rrr}
\hline & Tulum Cheese & White Cheese & Kashar Cheese \\
\hline Dry matter (\%) & $58.98 \pm 0.51$ & $28.64 \pm 1.33$ & $51.72 \pm 0.01$ \\
PH & $4.85 \pm 0.01$ & $4.89 \pm 0.01$ & $5.32 \pm 0.02$ \\
Salt (\%) & $4.42 \pm 0.01$ & $3.05 \pm 0.02$ & $2.00 \pm 0.01$ \\
Fat (\%) & $32.17 \pm 0.29$ & $12.17 \pm 0.29$ & $20.17 \pm 0.29$ \\
\hline
\end{tabular}

All chemical analyses were performed in duplicate and given as mean \pm standard deviation.

Table 2 Microbiological changes $(\log \mathrm{cfu} / \mathrm{g})$ of freeze dried cheese samples during six months of storage

\begin{tabular}{|c|c|c|c|c|c|}
\hline & \multicolumn{5}{|c|}{ Months } \\
\hline & 0 & 1 & 2 & 3 & 6 \\
\hline \multicolumn{6}{|c|}{ Kashar Cheese } \\
\hline TMAB & $5.90 \pm 0.06 \mathrm{~A}$ & $3.84 \pm 0.01 \mathrm{~B}$ & $4.11 \pm 0.19 \mathrm{~B}$ & $2.46 \pm 0.15 \mathrm{C}$ & $2.30 \pm 0.30 \mathrm{C}$ \\
\hline YM & $4.92 \pm 0.07 \mathrm{~A}$ & $2.15 \pm 0.21 \mathrm{~B}$ & $3.87 \pm 0.03 \mathrm{C}$ & $2.09 \pm 0.10 \mathrm{C}$ & $2.10 \pm 0.17 \mathrm{C}$ \\
\hline LAB & $4.94 \pm 0.01 \mathrm{~A}$ & $3.32 \pm 0.02 \mathrm{~B}$ & $2.98 \pm 0.07 \mathrm{~B}$ & $<1 \mathrm{C}$ & $<1 \mathrm{C}$ \\
\hline CNS & $2.95 \pm 0.09 \mathrm{~A}$ & $2.16 \pm 0.15 \mathrm{~A}$ & $2.30 \pm 0.17 \mathrm{~A}$ & $2.24 \pm 0.34 \mathrm{~A}$ & $<1 \mathrm{~B}$ \\
\hline $\mathrm{C}$ & $<1$ & $<1$ & $<1$ & $<1$ & $<1$ \\
\hline \multicolumn{6}{|c|}{ Tulum Cheese } \\
\hline TMAB & $7.71 \pm 0.10 \mathrm{~A}$ & $6.27 \pm 0.15 \mathrm{D}$ & $6.95 \pm 0.12 B$ & $6.64 \pm 0.04 \mathrm{C}$ & $5.44 \pm 0.06 \mathrm{E}$ \\
\hline YM & $7.37 \pm 0.06 \mathrm{~A}$ & $6.01 \pm 0.07 \mathrm{D}$ & $6.88 \pm 0.09 \mathrm{~B}$ & $6.46 \pm 0.04 \mathrm{C}$ & $5.15 \pm 0.21 \mathrm{E}$ \\
\hline LAB & $6.97 \pm 0.02 \mathrm{~A}$ & $6.03 \pm 0.04 \mathrm{C}$ & $6.37 \pm 0.06 \mathrm{~B}$ & $6.10 \pm 0.04 \mathrm{C}$ & $5.06 \pm 0.06 \mathrm{D}$ \\
\hline CNS & $6.92 \pm 0.02 \mathrm{~A}$ & $6.77 \pm 0.02 \mathrm{~B}$ & $6.80 \pm 0.01 \mathrm{~B}$ & $6.40 \pm 0.08 \mathrm{C}$ & $5.63 \pm 0.06 \mathrm{C}$ \\
\hline $\mathrm{C}$ & $<1$ & $<1$ & $<1$ & $<1$ & $<1$ \\
\hline \multicolumn{6}{|c|}{ White Cheese } \\
\hline TMAB & $5.70 \pm 0.07 \mathrm{CD}$ & $6.96 \pm 0.57 \mathrm{~A}$ & $6.16 \pm 0.15 \mathrm{BC}$ & $6.75 \pm 0.05 \mathrm{AB}$ & $5.50 \pm 0.63 \mathrm{D}$ \\
\hline YM & $5.12 \pm 0.15 \mathrm{~B}$ & $6.66 \pm 0.57 \mathrm{~A}$ & $4.64 \pm 0.15 \mathrm{~B}$ & $3.20 \pm 0.17 \mathrm{C}$ & $2.97 \pm 0.06 \mathrm{C}$ \\
\hline LAB & $4.92 \pm 0.03 \mathrm{~B}$ & $5.29 \pm 0.11 \mathrm{~A}$ & $3.85 \pm 0.11 \mathrm{C}$ & $2.98 \pm 0.02 \mathrm{D}$ & $2.30 \pm 0.00 \mathrm{E}$ \\
\hline CNS & $4.19 \pm 0.02 \mathrm{~A}$ & $3.45 \pm 0.21 \mathrm{~B}$ & $2.77 \pm 0.01 \mathrm{C}$ & $2.16 \pm 0.15 \mathrm{D}$ & $1.95 \pm 0.05 \mathrm{D}$ \\
\hline $\mathrm{C}$ & $<1$ & $<1$ & $<1$ & $<1$ & $<1$ \\
\hline
\end{tabular}

Data are expressed as means \pm standard deviation $(\mathrm{n}=3)$, TMAB: Total Mesophilic Aerobic Bacteria, LAB: Lactic Acid Bacteria, CNS: CoagulaseNegative Staphylococci, YM: Yeast and Molds, C: Coliform 


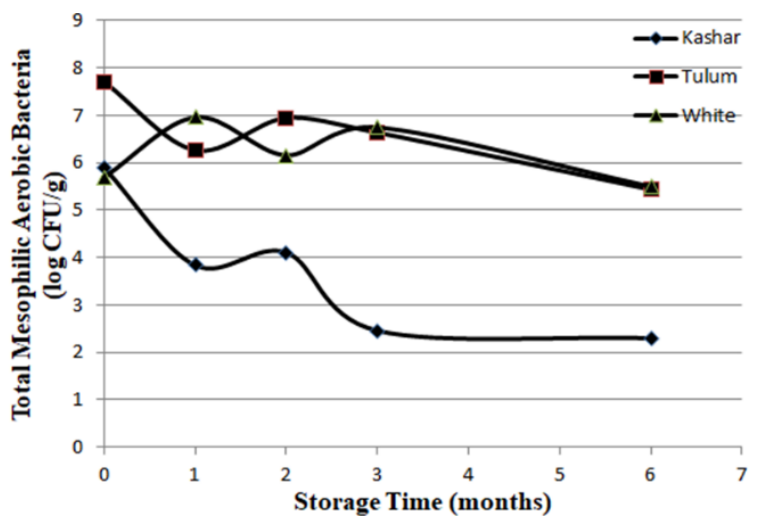

Figure 1 The changes in the number of Total Mesophilic Aerobic Bacteria during storage

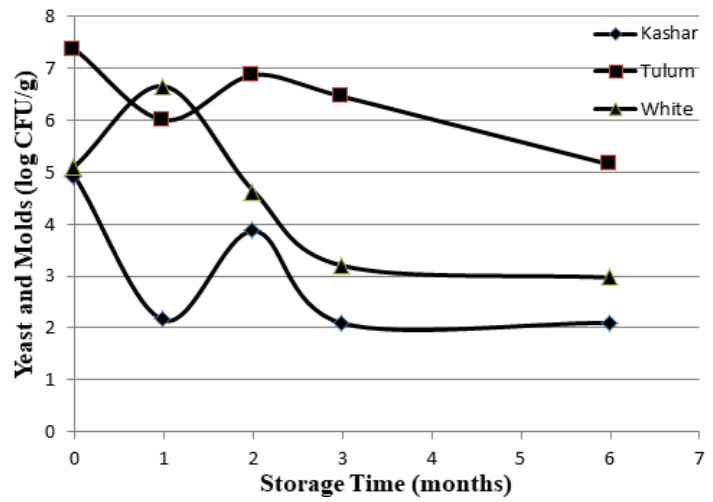

Figure 2 The changes in the number of Yeast and Molds during storage

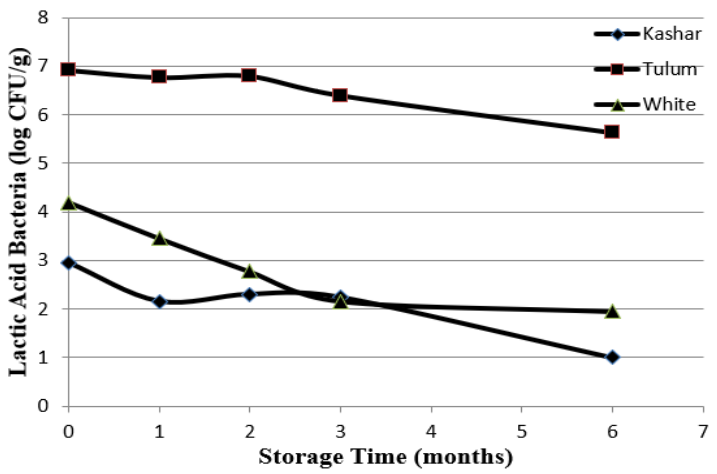

Figure 3 The changes in the number of Lactic Acid Bacteria during storage

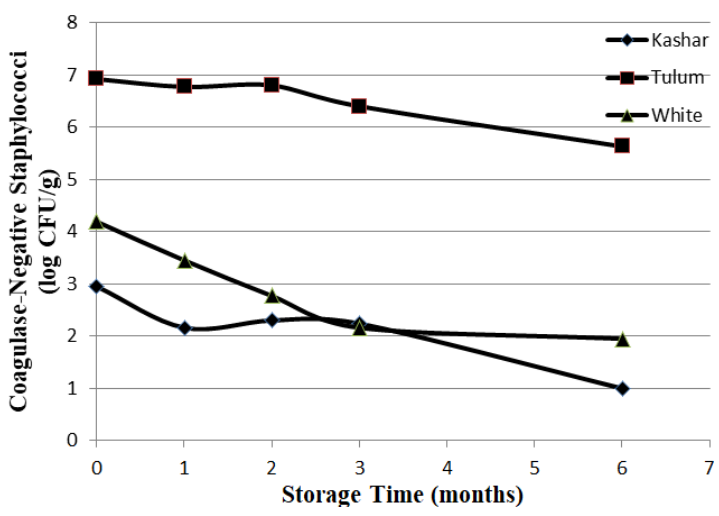

Figure 4 The changes in the number of CoagulaseNegatice Staphylococci during storage
Coagulase-Negative Staphylococci (CNS) are found in nature commonly and isolated from various types of foods. Major foods which contains high numbers of CNSs are ripened fermented foods like cheeses and sausages (Coton et al., 2010). In our study CNS counts were $2.95,6.92$, and $4.19 \log \mathrm{cfu} / \mathrm{g}$ in Kashar, Tulum and White cheese samples respectively. The highest number was found in Tulum cheese and a decrease was observed during 6 months of storage for all three cheeses.

The quality of raw milk, heat treatment, activity of the starter culture and the salting process are the most important factors for controlling the number of undesirable microorganisms during manufacturing (Bintsis and Papademas, 2002). The most important indicators of these types of contaminants are coliform group bacteria. In this study coliform group bacteria was not detected in any of the cheeses. Similarly, Arıcı and Şimşek (1991) did not determine coliform bacteria in cheese samples manufactured by starter culture.

\section{Conclusion}

Lyophilization is the most favourable method compared to other dehydration techniques. This method is preferred because of its advantages such as conservation of the original shape, less flavour losses and closeness to the un-dehydrated status of the food. The main disadvantage of freeze drying method is the high investment cost, thus it is not widely used. On the other hand, in recent years Lyophilization is thought to be the best choice for drying foods than any other method.

Freeze dried cheeses are widely used as an ingredient in food industry. Freeze dried cheeses provide some ease of use compared to conventional cheeses. They are easily mixed with other food components, can be stored for longer times and they maintain flavour and functional properties better. Dried cheeses are also used in salad dressings, soups, souffles, cakes and some other special bakery products such as chips, pasta, biscuits, and pizza in food industry.

\section{References}

Abdalla MI, El Zubeir IYM, Ahmed AHR, Mohamed BW. 2012. Microbiological quality of Sudanese White cheese during storage using different packaging materials. Annals. Food Sci Techn., 13(1):53-59.

Anonymous. 1978. Türk standartları enstitüsü, Peynirde yağ miktarı tayini (Van Gulik metodu), Ankara.

Andritsos N, Dalampakis P, Kolios N. 2003. Use of geothermal energy for tomato drying. GHC Bulletin, March 9-13.

AOAC. 2000a. Offical Method 926.124. Acidity of cheese. Titrimetric Method. Official Methods of analysis of AOAC International, Vol. 2, 17th ed., Gaithersburg, USA.

AOAC, 2000b. Official method 975.20. Salt in cheese. Official Methods of Analysis of AOAC International, Vol:2, 17th ed., Gaithersburg, USA.

Arıcı M, Şimşek O. 1991. Kültür kullanımının tulum peynirinin duyusal, fiziksel, kimyasal ve mikrobiyolojik özelliklerine etkisi. G1da, 16(1): 53-62.

Badem A, Uçar G. 2016. A study on chemical and microbiological properties of Kashar cheese produced without using starter culture. Eurasian J Vet Sci, 32(3): 188192. DOI: 10.15312/EurasianJVetSci.2016318399. 
Bintsis T, Papademas P. 2002. Microbiological quality of WhiteBrined cheeses: a review. Int J Dairy Technol, 55(3): 113120. DOI: $10.1046 / j .1471-0307.2002 .00054 . x$

Ciurzyriska A, Lenart A. 2011. Freeze-drying- application in food processing and biotechnology- a review. Pol. J. Food Nutr. Sci., 61(3):165-171.

Coton E, Desmonts MH, Leroy S, Coton M, Jamet E, Christieans S, Donnio PY, Lebert I, Talon R. 2010. Biodiversity of coagulase-negative staphylococci in french cheeses, dry fermented sausages, processing environments and clinical samples. Int J Food Micro, 137: 221-229.

Çetinkaya F, Soyutemiz E. 2006. Microbiological and chemical changes throughout the manufacture and ripening of Kashar: a traditional Turkish cheese. Turk. J. Vet. Anim. Sci., 30, $397-$ 404.

Demirci M, Diraman H. 1990. Trakya bölgesinde üretilen vakum paketlenmiş taze kashar peynirlerinin yapım tekniği, fiziksel, kimyasal ve mikrobiyolojik nitelikleri ve enerji değerleri üzerinde bir çalışma. Gıda, 15(2), 83-88.

Dincer I, Hussain MM, Sahin AZ, Yilbas BS. 2002. Development of a new moisture transfer (Bi-Re) correlation for food drying applications. Int J Heat and Mass Trans, 45: 1749-1755.

Düzgüneş O, Kesici T, Kavuncu O, Gürbüz F. 1987. Araştırma ve deneme metotları. Ankara Üniversitesi, Ziraat Fakültesi Yayınları, Ankara, 381s.

Erbay Z, Koca N, Kaymak-Ertekin F, Ucuncu M. 2015. Optimization of spray drying process in cheesepowder production. Food and bioproducts processing, 93: 156-165.

Genin N, Rene F. 1996. Influence of freezing rate and the ripeness state of fresh courgette on the quality of freeze-dried products and freeze-drying time. J Food Eng, 29: 201-209.

Hammami C, Rene F. 1997. Determination of freeze-drying process variables for strawberries. Jou J Food Eng, 32: 133154.

Henning DR, Baer RJ, Hassan AN, Dave R. 2006. Major advances in concentrated and dry milk products, cheese, and milk fat-based spreads. J Dairy Sci, 89(4): 1179-1188.

Karaman AD, Akbulut N. 2006. Kasar peynirinin raf ömrünün arttırılması üzerine bir arastırma. Türkiye 9. Gıda Kongresi; 24-26 Mayis 2006, Bolu.

Kaya S. 2004. Peynir kurutma metotları üzerine bir araştırma. Gida, 29(1): 89-93.

Kongo JM, Malcata FX. 2016. Cheese: chemistry and microbiology. reference module in food science encyclopedia of food and health. Elsevier, Netherlands, 753-740.

Krokida MK, Maroulis ZB. 2007. Effect of microwave drying on some quality shrinkage and porosity. Drying Technol, 17(3): 449-466.
Kurt A, Çakmakçı S, Çağlar A. 1991. Erzincan Tulum (Şavak) peynirinin yapılışı, duyusal, fiziksel ve kimyasal özellikleri üzerinde bir araştırma. Gida, 16(5): 295-302.

Küçüköner E. 2011. Peynir tozu ve peynir altı suyu tozu üretimi. 1. Ulusal Helal ve Sağlıklı Gıda Kongresi, 19-20 Kasım 2011, Ankara.

Leistner L. 2000. Basic aspects of food preservation by hurdle technology. Int J Food Microbiol, 55(1-3): 181-186.

Leistner L. 1992. Food preservation by combined methods. Food Res Int, 25: 151-158.

Marques LG, Prado MM, Freire JT. 2009. Rehydration characteristics of freeze-dried tropical fruits. Food Sci Technol, 42: 1232-1237.

Minitab 1991. Minitab reference manual release 8. pc. version. Minitab Inc., State College, P.A. Mmbaga, M.T., J.R.

Ozdemir C, Demirci M. 2006. Selected microbiological properties of Kaşar cheese samples preserved with potassium sorbate. Int J Food Prop, 9: 515-521.

Öner Z, Şimşek B, Sağdıç O. 2003. Determination of some properties of Turkish Tulum cheeses. Milchwissenschaft, 58(3/4): 152-154.

Öner Z, Karahan AG, Aloğlu H. 2005. some properties of Tulum cheese produced by using starter culture. G1da, 30(1): 57-62.

Pal M, Alemu J, Mulu S, Karanfil O, Parmar BC, Nayak JB. 2016. Microbial and hygienic aspects of dry milk powder. Beverage \& Food World , 43( 7): 28-31.

Papademas P. 2006. Halloumi cheese in brined cheeses. Blackwell Publishing Ltd., London: 117-136.

Pisecky J. 2005. Spray drying in the cheese industry. Int Dairy J, $15,531-536$.

Ratti C. 2001. Hot air and freze-drying of high-value foods: a review. J Food Eng, 49:311-319.

Savo I, Dragan M, Miladin B. 2012. Specificities of food freeze drying and product prices. Economics Agricul, 59(3):461471.

Serna-Cock L, Vargas-Munoz DP, Aponte AA. 2015. Structural, physical, functional and nutraceutical changes of freeze-dried fruit. African J Biotechnol, 14(6): 442-450.

Tayar M. 1995. Chemical and microbiological changes during the ripening of White Pickled Cheese. G1da, 20(2): 97-101.

Temiz H. 2009. Effect of modified atmosphere packaging on characteristics of sliced Kashar cheese. J Food Process Preser, 34: 926-943.

Veras AOM, Béttega R, Freire FB, Barrozo MAS, Freire JT. 2012. Drying kinetics, structural characteristics and vitamin c retention of dedo-de-moça pepper (Capsicum baccatum) during convective and freeze drying. Brazilian J Chem Eng, 29(04): 741-750. 